\title{
Unique autopsy case of primary cardiac lymphoma
}

\author{
Tomoki Fukui [ () , Nobuyuki Ogasawara, Shinji Hasegawa
}

Department of Cardiology, Japan Community Healthcare Organization Osaka Hospital, Osaka, Japan

\section{Correspondence to DrTomoki Fukui; tomoki.fukui@gmail.com}

Accepted 19 March 2021
Check for updates

(c) BMJ Publishing Group Limited 2021. No commercial re-use. See rights and permissions. Published by BMJ.

\begin{tabular}{|l|}
\hline To cite: Fukui T, \\
Ogasawara N, \\
Hasegawa S. BMJ Case \\
Rep 2021:14:e242174. \\
doi:10.1136/bcr-2021- \\
242174 \\
\hline
\end{tabular}

\section{DESCRIPTION}

A 92-year-old woman was admitted to hospital for dyspnoea. She was diagnosed for the first time with congestive heart failure. Her medical history included hypertension and diabetes. Chest radiography and electrocardiography revealed an enlarged heart and paroxysmal atrial fibrillation, respectively. Transthoracic echocardiography revealed preserved left ventricular systolic function, biventricular hypertrophy, dilated left atrium, right ventricular volume overload and mild pericardial effusion.

After medical treatment, her heart failure improved, and she was discharged after 2 weeks. However, 10 days post-discharge, she was readmitted for progressive fatigue and weight loss. Transthoracic echocardiography revealed hypovolaemia, negating the suspicion of recurrent congestive heart failure. Non-contrast CT unexpectedly revealed the enlargement of multiple lymph nodes in the mediastinal and pericardial spaces, and multiple masses adjacent to the heart. Blood tests revealed an elevated level of lactate dehydrogenase $(1035 \mathrm{U} / \mathrm{L}$, reference range 124-222 U/L). These findings suggested the presence of malignant lymphoma.

Considering her advanced frailty and dementia, the patient's family opted to initiate palliative care, and the patient died of disseminated intravascular coagulation and decompensated heart failure a month later. Postmortem examination revealed primary cardiac lymphoma (PCL). Notably, the heart structures were massively infiltrated, replaced and thickened by tumour tissue (figure 1). Histological analysis of tumour tissue demonstrated diffuse infiltration by lymphomatous large B-cells. Immunohistochemistry was positive for CD3 and MIB1, but negative for CD20, CD10, BCL6, MUM1 and cyclin D1 (figure 2).

PCL occurs rarely, accounting for $1 \%$ of primary cardiac tumours and $0.5 \%$ of extranodal lymphomas. ${ }^{12}$ PCL is defined as non-Hodgkin's lymphoma involving the heart and pericardium. Diffuse large B-cell lymphoma is its most common subtype. Although PCLs have previously been diagnosed on postmortem examinations because of difficult detection and very poor prognosis $(<$ less than 1 month if untreated), the advancement of imaging technology and treatment has enabled earlier detection, ultimately resulting in improved prognosis. Current literature describes the efficacy of chemotherapy, radiotherapy and surgical resection, enabling a prolonged median survival of approximately 4 years. ${ }^{3}$ However, a few cases have described the myocardial perforation due to tumour necrosis after chemotherapy. ${ }^{4}$

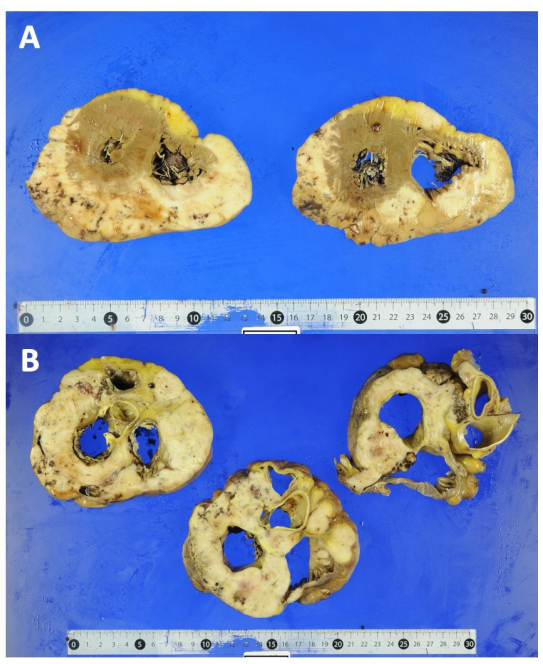

Figure 1 The cut surface of the heart. Both ventricles and both atria are massively infiltrated, replaced and thickened by tumour tissue. Tumour tissue extends to the pericardium and superior vena cava. (A) At the level of ventricle. (B) At the level of atrium.

Clinical presentations of PCL differ depending on each case, with typical presentations of dyspnoea, congestive heart failure, arrhythmia and pericardial effusion. Cardiac masses frequently involve the right atrium and right ventricle (92\%), extending to the left-side heart, superior vena cava $(25 \%)$ and other cardiac structures. ${ }^{1}$ However, diffuse infiltration, as seen in our case, is extremely rare. In this case, diffuse infiltration represented biventricular hypertrophy and subsequent enlarged heart antemortem. We initially assessed her heart failure as hypertensive heart disease from her medical history, which lead to the delayed diagnosis.

Currently, there are only a few reports describing the autopsies of untreated PCLs. ${ }^{5}$ This is a rare present-day case of an autopsy showing untreated

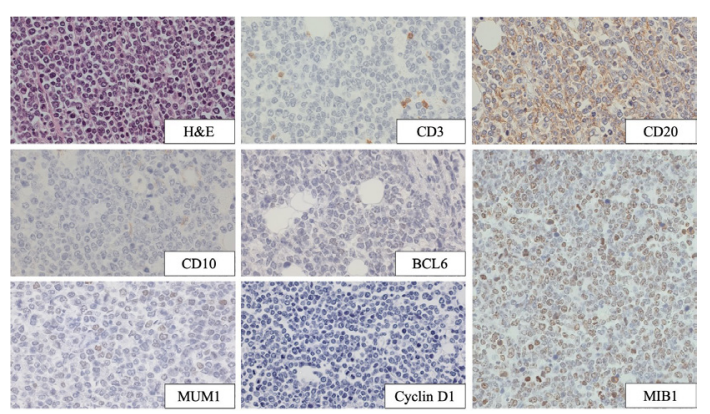

Figure 2 Histology of tumour tissue demonstrating diffuse infiltration by lymphomatous large B-cells. Immunohistochemistry is positive for CD3 and MIB1, but negative for CD20, CD10, BCL6, MUM1 and cyclin D1. 
end-stage PCL in a woman of advanced age, where a B-cell lymphoma massively infiltrated and uncommonly involved all four cardiac chambers, resulting in death 2 months after her first episode of heart failure. This case emphasises the recognition of histopathological presentation on autopsy and the natural course of an advanced PCL.

\section{Learning points}

Primary cardiac lymphoma (PCL) occurs rarely, with a very poor prognosis if untreated. Modern-day medical practice has resulted in few reports describing the autopsy cases of untreated PCLs.

- This is a rare case of autopsy showing advanced PCL, where the B-cell lymphoma subtype massively infiltrated and uncommonly involved all four cardiac chambers.

- Diffuse infiltration of lymphoma can represent ventricular hypertrophy, mimicking hypertensive heart disease, which can lead to a delayed diagnosis of PCL.
Contributors The paper was authored by TF: conception and design, writing the article; NO: final approval of the manuscript; and SH: final approval of the manuscript.

Funding The authors have not declared a specific grant for this research from any funding agency in the public, commercial or not-for-profit sectors.

Competing interests None declared.

Patient consent for publication Obtained.

Provenance and peer review Not commissioned; externally peer reviewed.

\section{ORCID iD}

Tomoki Fukui http://orcid.org/0000-0001-9335-9079

\section{REFERENCES}

1 Petrich A, Cho Sl, Billett H. Primary cardiac lymphoma: an analysis of presentation, treatment, and outcome patterns. Cancer 2011;117:581-9.

2 Gowda RM, Khan IA. Clinical perspectives of primary cardiac lymphoma. Angiology 2003:54:599-604.

3 Sultan I, Aranda-Michel E, Habertheuer A, et al. Long-Term outcomes of primary cardiac lymphoma. Circulation 2020;142:2194-5.

4 Ceresoli GL, Ferreri AJ, Bucci E, et al. Primary cardiac lymphoma in immunocompetent patients: diagnostic and therapeutic management. Cancer 1997;80:1497-506.

5 Lee PW, Woo KS, Chow LTC, et al. Diffuse infiltration of lymphoma of the myocardium mimicking clinical hypertrophic cardiomyopathy. Circulation 2006;113:e662-4.

Copyright 2021 BMJ Publishing Group. All rights reserved. For permission to reuse any of this content visit

https://www.bmj.com/company/products-services/rights-and-licensing/permissions/

BMJ Case Report Fellows may re-use this article for personal use and teaching without any further permission.

Become a Fellow of BMJ Case Reports today and you can:

- Submit as many cases as you like

- Enjoy fast sympathetic peer review and rapid publication of accepted articles

- Access all the published articles

Re-use any of the published material for personal use and teaching without further permission

Customer Service

If you have any further queries about your subscription, please contact our customer services team on +44 (0) 2071111105 or via email at support@bmj.com.

Visit casereports.bmj.com for more articles like this and to become a Fellow 